\title{
Legal Protection Of Contract Employees Agreement In The Implementation Of Certain Time In Kendal (National Land Agency)
}

\author{
Aldila Marselli ${ }^{1}$, Sunardi ${ }^{2}$ and Sri Endah Wahyuningsih ${ }^{3}$
}

Abstract. Reforms in the field of employment law is done with the purpose to improve and enhance the quality of labor and personnel welfare. Reformation in the field of employment law begins with the issuance of Act No. 21 of 2000 concerning Trade Union / Labor United. Then followed with the release of Act No. 13 of 2003 on Manpower. Problems in this research: (1) To identify and analyze the Implementation of the Employment Agreement in the Specific Time (PKWT) At the National Land Agency of Kendal. (2) To identify and analyze the forms of legal protection for workers at National Land Agency of Kendal with the Specific Time of Work Agreement (PKWT). The results of this study are: (1) Implementation of the Employment Agreement in the Specific Time (PKWT) at the Land Office of Kendal by implementing probation on each worker who recruits including contract workers. Which it is not supposed to apply probation at a certain time and labor agreements remain to be done if the employment agreement becomes null and void. (2) The legal protection of workers / laborers at Specific Time Work Agreement (PKWT) inemployeein practice has not run optimally, given the frequent violations, because of the vagueness of the rules on the implementation of the Employment Agreement for specific time periods, in providing protection against labor law for employees in the Land Office of Kendal.

Keywords: Legal Protection; Labor Contract; the National Land Agency.

\section{Introduction}

The field of employment governing the employment relationship between employers and employees, where employers give orders work to be performed by the worker, and the worker will be rewarded in return for the work he has done. Work is an attempt by someone to earn a living in order to meet all their needs. In an effort to earn such income, someone else would need another person in a relationship of mutual assistance and exchange of help in giving all that has been owned and receive all what is still needed from others. Someone who lack the capital or income is what will require work to provide income to him, at least a limited ability. ${ }^{4}$

Reforms in the field of employment law is done with the aim to improve and enhance

\footnotetext{
1 Master of Notary's Student, Faculty of Law, Universitas Islam Sultan Agung email aldilamarselli@gmail.com

2 Students of Master of Law, Faculty of Law, Universitas Islam Sultan Agung email myongardi@gmail.com

3 Lecturer of Faculty of Law UNISSULA

${ }^{4}$ A. Ridwan Hilmim 1987 Sari Hukum Pemburuhan Jakarta: PT. Pradnya Paramita p. 3
} 
the quality of labor and personnel welfare. Reformation in the field of employment law begins with the issuance of Act No. 21 of 2000 concerning Trade Union / Labor United. Then followed with the release of Act No. 13 of 2003 on Manpower.

However, in practice at the present time, the purpose of the reform legislation in the field of employment conducted with the aim to provide a sense of justice and the protection of workers as well as to fulfill the mandate of the Act of 1945 is to carry out the construction of Indonesia fully human and community development Indonesia entirely, and to enhance the dignity, dignity and self-employment and to realize a prosperous society, just, prosperous and equitable both materially and sprituil not run in accordance with the aspired. The cause of these effects there are a variety of factors, one of which is by way of employing workers with a labor agreement system Specific Time (PKWT).

The problems that will be studied is how Implementation of the Employment Agreement in the Specific Time (PKWT) At the National Land Agency of Kendal and how the forms of legal protection for workers Specific Time Work Agreement (PKWT) on National Land Agency of Kendal.

\section{Research Methods}

The method used in this research is juridical sociological method. Juridical Sociological is a legal research using secondary data as the first data, followed by primary data or field data. Examining the effectiveness of a Law and Research wants to find a relationship (correlation) between a variety of symptoms, or variable as a means of collecting data consists of the study of documents, observation and interview. ${ }^{5}$

\section{Discussion}

\subsection{The Implementation of the Employment Agreement in the Specific Time (PKWT) at the Land Office of Kendal}

The specific time work agreement has taken place in 1 year with renewal every year, which means that the employment agreement continuously extended. According to the provisions of Article 59 paragraph (6) of Act No. 13 of 2003 and the implementing regulations are KEP.100 / MEN / VI / 2004, contracts that particular time in the Land Office of Kendal based on the Regulation of the National Land Agency of the Republic of Indonesia No. 22014 on Employees Environment Variable in the National Land Agency.

Implementation of the overall field of land conducted by the National Land Agency of Kendal which is a unit located BPN Regency / City in the province of Central Java. The authority of the National Land Agency of Kendal is under and is responsible to the Minister which is also the Head of BPN through the Head of BPN Regional Office and headed by the National Land Agency.

Based on the provisions contained in the Act of 2003 on Labor Nomor.13, execution of the work contract system is not prohibited, because in reality there are two (2) forms

\footnotetext{
${ }^{5}$ Amiruddin 2012 Pengantar Metodologi Penelitian Hukum Jakarta: RajaGrafindo Persada p. 15
} 
of the implementation of the employment agreement specified time that is practiced, that there is agreement in the Specific Time (PKWT) conducted between workers / laborers by employment services company.

The specific time work agreement has taken place in 1 year with renewal every year, which means that the employment agreement continuously extended. According to the provisions of Article 59 paragraph (6) of Act No. 13 of 2003 and the implementing regulations are KEP.100 / MEN / VI / 2004, contracts that particular time in the National Land Agency of Kendal based on the Regulation of the National Land Agency of the Republic of Indonesia No. 22014 concerning Employees Environment Variable in the National Land Agency.

Particular time work agreement between the National Land Agency of Kendal by employees of the National Land Agency of Kendal contained in a certain time employment agreement attached as a contract worker at the National Land Agency Kendal, the worker is placed as a computer operator. The corresponding status is as contract workers, in which the contract terms are employment agreement specified time according to the Employment Act a maximum period of 3 (three years), but according to the results of the confirmation by the National Land Agency of Kendal as employer, concerned has worked for 1 (one) uninterruptedly with each 1 (one) year to renew the contract and following the selection again. ${ }^{6}$

In Article 59, paragraph (6) of Act No. 13 of 2003, renewal work agreement specified time should only be done 1 (one) time period of 2 (two) years and renewal work agreement this particular time will be held after the exceeding grace period 30 days of the expiration of certain employment agreement a long time. As for the specific time employment agreement between the employee or contract employee with the National Land Agency of Kendal made within a period of one (1) year to update them on an ongoing basis if the period of employment would be exhausted.

Based on Act No. 13 of 2003, renewal work agreement specified time a worker can only be done one time with a maximum period of one tahun.Mengacu on the provisions of the agreement to renew labor practices specified time many times is something that violates the provisions of , In the world of labor, easily met workers who have many years of working in an institution or company his worker status are still bound by a labor agreement. Any several government agencies who try to outsmart the rules to renew the contract employees repeatedly.

\subsection{Legal Protection for Workers at the Land Office in the Specific Time Work Agreement (PKWT) in Kendal}

Actually, when viewed in Act No. 13 of 2003 on Manpower existing protection afforded to workers / laborers, including those who work with the system of contract or labor agreement in the Specific Time (PKWT). Only in its application is not all that is done in accordance with the provisions of existing laws, especially those related to labor.

According Supomo in Asikin quoted by Abdul Hakim, labor protection can be divided

\footnotetext{
${ }^{6}$ Vinni MelianaInterview National Land Agency in Kendal interview on June 62018.
} 
into three types, namely: ${ }^{7}$

- Economical protection; Namely the protection of labor in the form of an adequate income, including if the workforce is not able to work out his will.

- Social protection; Namely the protection of labor in the form of health insurance work, freedom of association and protection to organize.

- Technical protection; Namely the protection of labor in the form of security and safety.

That the union / labor united is not the interpreter of the Act, but the implementing the legislation. If the unions / labor united assume no chapter or article of the Act No. 13 of 2003 which is detrimental to workers / laborers should be communicated, consulted and discussed in the Tripartite Cooperation Institution. The results are then submitted to government deliberation.

Unions are also entitled to participate in PKB. The Act No. 21 of 2000 concerning Trade Union / Labor United Ratified and promulgated on August 4 2000. From the passed and enacted Act No. 21 of 2000 established many unions / labor unions. that the Act No. 21 of 2000 and Act No. 13 of 2003 were born first is the Act No. 21 of 2000. In the arrangement of Act No. 13 of 2003 of course Unions / labor Unions helped participation. And now the contract system and outsourcing work much talked about because it is considered detrimental to workers / laborers. The labor united/ trade unions participated in drafting the Act No. 13 of 2003 but the union workers also were refused.

Labor offices in Kendal should seek proactive in seeing the issue of the Labor which happens to employees at the National Land Agency of Kendal, So that problems that occur can be directly solved by the Department of Labor in Kendal, So that the system implementation work agreement in the Specific Time (PKWT) in employees National Land Agency of Kendalcan be run in accordance with the provisions of the Employment Act in force in Indonesia.

Labor protection as set out in Act No. 13 of 2003 on Labor aims to assure a harmonious working relationship between the worker / laborer with the National Land Agency of Kendal without pressures from the strong to the weak. Therefore, the National Land Agency of Kendal are socio-economically have a strong position required to help implement the provisions of such protection in accordance with the legislation in force. In Act No. 13 of 2003 on Labor and its implementing the regulations have arranged a variety of protection of workers / laborers, including workers / laborers who wears the Specific Time Work Agreement (PKWT).

When in actual use, the National Land Agency of Kendal who use the workers / laborers with systems Specific Time Work Agreement (PKWT) does not comply with the provisions set forth in Article 59 paragraph (1) of Act No. 13 of 2003 on the Labor, there are sanctions that would received by the National Land Agency of Kendal which is also a form of protection provided by Act No. 13 of 2003 on labor, which is stipulated in Article 59 paragraph (7), which reads: a work agreement for a specified time does

\footnotetext{
${ }^{7}$ Abdul Hakim 2003 Pengantar Hukum Ketenagakerjaan Indonesia Bandung: PT. Citra Aditya Bakti p. 61-62.
} 
not comply with the provisions referred to in paragraph (1), paragraph (2), (4), subsection (5) and (6), then by law be a work agreement for an unspecified time.

\section{Closing}

\subsection{Conclusion}

From the discussion presented in the previous chapter can be concluded as follows:

- Implementation of the Employment Agreement in the Specific Time (PKWT) at the Land Office of Kendal by implementing probation on each worker who recruits including contract workers.

- In which it is not in accordance with the provisions of Article 58 of Act No. 13 of 2003, which requires not implement probation at a certain time and labor agreements remain to be done if the employment agreement becomes null and void.

- Legal protection of the worker / laborer in the Specific Time Work Agreement (PKWT) inemployee in practice has not run optimally, given the frequent violations, because of the vagueness of the rules on the implementation of the Employment Agreement for specific time periods, particularly with regard to the specific job according to the type and nature of the work will be completed within a certain time, that job once completed or temporarily nature, work expected completion in the not too long and not more than three (3) years, in providing legal protection of labor for employees in the District Land Office of Kendal, there is a supervisor in the structure of the Department of Manpower and Transmigration (Manpower) Kendal as well as the Tripartite Cooperation Institution (LKS Tripartite) which is a forum for communication, consultation and deliberation on labor issues, in addition to the Employment Act has provided protection for workers / employees

\subsection{Suggestions}

- In every employment contract system using Work Agreement in the Specific Time (PKWT) should be made the premise or background, which is a kind description of the work to be done, so that for any labor agreement in the Specific Time (PKWT) made it became clear to the workers / laborers, or regarding the requirements for the type and nature of work has been regulated by the government, should be submitted only to the needs of the parties.

- Because the worker / contract labor / labor agreement in the Specific Time (PKWT) did not receive various benefits and facilities as it is accepted by the worker / laborer with a system of labor agreement for specific time unspecified (PKWTT), then you should pay given to workers / laborers with the system agreement working time (PKWT) further improved or adapted in the form of a sort of minimum wage for workers / laborers and systems work agreement in the Specific Time (PKWT) for the protection for them, because you will not be renewed his contract or get a job again in the future if they are in Stop (PHK). By increasing their wages are expected welfare is also increasing 


\section{References}

[1] Ridwan Hilmim 1987 Sari Hukum Pemburuhan Jakarta: PT. Pradnya Paramita

[2] Act No. 13 of 2003 Regarding Employment

[3] Act No. 5 of 1960 About the Basic Regulation of Agrarian.

[4] Amiruddin 2012 Pengantar Metodologi Penelitian Hukum Jakarta: RajaGrafindo Persada Abdul Hakim 2003 Pengantar Hukum Ketenagakerjaan Indonesia Bandung: PT. Citra Aditya Bakti

[5] Law on Social Security of Labor Act No. 3 In 1992, LN No. 14 of 1992, Supplement No. 3468, part explanation.

[6] Law on the National Social Security System Act No. 40 of 2004, LN No. 150 of 2004, Supplement No. 4456, part explanation.

[7] Regulation of the National Land Agency of the Republic of Indonesia Number 4 of 2006 the organizational structure of the land office

[8] Regulation of the National Land Agency of the Republic of Indonesia Number 2 of 2014 on Employees Environment Variable in the National Land Agency 